\title{
Online Debating as a Pedagogy for Enhancing Argumentative Writing and Reducing Writing Apprehension among EFL Majors
}

\author{
Dr. Hanan Gamal Mohamed Ebedy*
}

\begin{abstract}
The purpose of this study was to investigate the effect of online debating in enhancing argumentative writing and reducing writing apprehension for fourth year EFL majors at the Faculty of Languages and Translation, Misr University for Science and Technology. Participants of the study, totaling 50 students, were divided into two equal groups randomly assigned to the experimental and control groups. To fulfill the purpose of the study, two instruments were developed and validated; an argumentative writing test and a DM-writing apprehension test. They were administered as a pre- posttest for both groups before and after the 11 weeks training program. The experimental group received the online debating training program treatment, whereas the control group students followed their regular method of teaching writing. Results indicated that the online debating program was effective in enhancing EFL majors' argumentative writing and reducing their writing apprehension. It was recommended that teaching the structural features of online debating should be incorporated into language pedagogy program.
\end{abstract}

Keywords: Online Debating, Argumentative Writing, Writing Apprehension

\section{Introduction}

The process of writing is infrequently stress-free even for professional writers, and it has been much neglected in the curriculum and less than efficiently dealt with in teaching. Since there is hardly no profession that does not need writing, language researchers regard writing a cornerstone of academic success. The regular method adopted is reduced to assigning topics and correcting errors with focus on grammar, ignoring the mental processes professional writers assume while performing their task.

EFL learners at the university level often face difficulties in the use of complex and appropriate elements in producing argumentative writing (Ka-kan-dee \& Kaur, 2015). Most EFL learners have partial understandings of argument; for instance, a for-and-against structure inserted between introduction and conclusion. Consequently, learners need to develop analytic and evaluative skills in order to write effective argumentative essays, and

*Lecturer of Curriculum and Instruction (TEFL) Misr University for Science and Technology-Egypt

Email: pear11282006@yahoo.com

Received on: 30 / 4 / 2021 - Accepted for publication on: 18 /5 /2021- E-published on: 6 /2021 
learners need to be aware of the appropriate schematic structure, style, and register for effective presentation of their position (Schwarz, et al., 2003; Wu, 2006; Zohar \& Nemet, 2002).

Despite the fact that university students' competence of producing written content is crucial for academic success, they are not often satisfied about their writing which is represented by course avoidance and expressing a negative attitude about the usefulness of writing as well as ignoring jobs requiring writing (Hammann, 2005; N. S. Daud, N. M. Daud, \& Kassim, 2005; Erkan \& Saban, 2011; and Al-Shboul \& Huwari, 2015). Research maintains that students' reluctance to write might be due to 'writing apprehension' (Onwuegbuzie, 1997). Consequently, this difficulty requires to be tackled by researchers and teachers.

Writing is viewed as bi-dimensional process, comprising both emotional and cognitive abilities, in which students not only learn to write but also develop an attitude towards the act of writing (Cheng, 2002). Daly and Miller (1975) defined writing apprehension as a state of psychological interaction comprising emotions, attitude, and behavior consolidating each other (p. 11). Recent research use writing apprehension interchangeably with anxiety and blocking (Singh \& Rajalingam, 2012). Researchers view writing apprehension as an intricate term portraying a real problem that can preclude performance of native speakers and foreign language learners alike (Zumbrunn, et al., 2013).

As writing and critical thinking are tightly interwoven and critical thinking is crucial in knowledge-society, argumentative writing has been strongly demanded from university students particularly English majors. Argumentative writing is highly effective in demonstrating critical thinking as students analyze, assess and give counter-argumentation to opposing views to persuade the reader (Flores, 2006; Golpour, 2014; Samanhudi, 2011; Hashemi et al., 2014; and Nikou, Bonyadi \& Amirikar 2015). However, a great number of students are unable to meet these expectations (Shahsavar, 2012).

In this digital age, research indicates that there is a relationship between developing critical thinking and the use of online learning (MacKnight, 2000). In a study conducted by Shahsavar (2012), results revealed that online learning can be effectively employed to enhance critical thinking and argumentative writing. One possible recommended strategy for argumentative writing is 'the structured format of online debating which is strongly advocated in recent research (Conrad and Donaldson, 2004; William \& Mostert, 2005; Mont, 2014).

Current research claim that online debating could be useful for enhancing critical thinking in the writing of university level students, yet research about critical thinking in argumentative writing is still needed. To meet this need, the present study attempts to investigate the effect of online debate in developing argumentative writing and reducing writing apprehension. 


\section{Review of Literature}

Recent research advocates teaching writing as a process in which ideas are translated into tangible language and are likely to raise EFL students' awareness of the processes assumed by advanced writers, starting by exploring topics, and ending with publishing the finished content (Baily,2003; and Oshima \& Hoggue, 2005). In a word, the main focus in the process approach is on the composing processes like planning and drafting rather than linguistic knowledge like grammar and text structure (Badger \& White, 2000).

Argumentative writing is highly demanded in university assignments, but unfortunately, most EFL students have difficulty arguing for or against a thesis statement, in which they are required to find evidence to back up the claim presented and provide evidence to persuade readers of a controversial issue or adopt a particular action. Nippold and WardLonergan (2010, p. 238) note that "argumentative writing is a challenging communication task that needs sophisticated cognitive and linguistic abilities". According to Richards and Schmidt (2010), argumentative writing is an attempt to back a controversial issue or defend a disputable opinion. In argumentation, students are required to perform rigorous intellectualisms with a critical perspective. Thus, the crucial component necessary for teaching argumentative writing is that of critical thinking.

Researchers have determined that argumentative writing is the most difficult form of writing (Ferretti, Andrews-Weckerly \& Lewis, 2007; and Neff-van Aertselaer \& DafouzMilne, 2008). This type of writing is crucial for university students who need to express themselves in academically acceptable ways and strategies. Unfortunately, EFL students often struggle to write argumentative essays (Watcharakaweesilp, 2005; and Thepsiri \& Pojanapunya, 2013).

It is common knowledge that how a student thinks about a learning task has a significant impact on how well s/he performs on that task. Teachers of writing had a tendency in the past to attribute students' poor performance to their poor attitude toward writing. The same teachers believe that students who have developed a positive attitude about writing are more likely to write well in any assignment. As a matter of fact, teachers are strongly required to boost students' attitude instead of adopting this simple way of analysis. Professional teachers, on the other hand, recognize the value of positive writing interactions and reviews, and usually attempt to upgrade students' level of motivation in their writing classes (Atay \& Kurt, 2006). For some students, writing is a pleasurable practice when they put their thoughts or ideas on paper. For students who are reluctant to put their thoughts into writing, this activity can be a very uncomfortable, if not terrifying, experience each time they are given a written assignment (Vanhille, Gregory \& Corser, 2017). It is normal for students to have different levels of enjoyment and interest in writing, which is referred to as writing apprehension. As a result, learners with varying levels of writing ability can experience varying levels of anxiety when writing.

When faced with a writing task, some learners may experience an intensive sense of fear coupled with anxiety for a variety of reasons, including fear of being judged, a lack or 
limited experience and self-confidence, or a history of poor writing results (Vanhille, Gregory, \& Corser, 2017). Other reasons for writing apprehension include a dislike of writing or making one's work liable to evaluation (Autman \& Kelly, 2017). Writing anxiety or apprehension, according to Takahashi (2009), is described as a "fear of the writing process that outweighs the projected benefit from the ability to write." The impact of writing apprehension on writing performance can be used as a measure of writing quality. For example, Daud \& Abu Kassim (2005) found that students with low-apprehension perform better in writing classes than those with high-apprehension and their writing product amount is three-fold that of high-apprehension students.

Recent research identified features of apprehension (Öztürk \& Çeçen, 2007; Kara, 2013; and Al-Shboul \& Huwari, 2015). Writing apprehensive people are generally afraid of being forced to write; they are afraid of being judged represented by task avoidance or late delivery or even non-existent; and their fear of writing is reflected in their written product as well as their habits and attitudes toward writing tasks. In this regard, literature (Clark, 2005; Rankin-Brown, 2006; ztürk \& eçen, 2007; and Kara, 2013) referred to techniques to reduce or lessen writing apprehension among students. It is widely recognized that anxiety or apprehension negatively affects students' ability to write and may hinder their academic achievement.

Debate is a dynamic learning procedure that teaches students how to think more creatively while sharing their thoughts with others. It refers to activities in which two or more teams participate, with speakers from both sides debating their points of view and agreeing or disagreeing with one another on the issue presented. Hasibuan and Batubara (2012) maintain that debate is a pedagogy employed to improve learners' writing skills and critical thinking. Meanwhile, discussion in the classroom is used to teach students from all educational backgrounds how to compromise, agree, and discuss in a variety of contexts (Bellon, 2000). Debate is a cooperative learning method in which students are required to perform their roles in English language teaching and learning (Pradana, 2017).

Among the few studies that investigated the contribution of online debate to enhance learning is that undertaken by William and Mostert (2005). They depicted the format of the face-to-face debate, providing learners with clear guidelines to enhance their argumentation skills. This may give learners the opportunity to reflect on their answers and provide evidence for their claims. The advantage of online debate, according to Khalsi (2013), is to boost knowledge building, such as identifying roles or assignments to online debaters. Getting involved in online debates, she elaborates, promotes collaborative learning and critical thinking. In a study Park, Kier, and Jugdev (2011) to probe debate as a teaching strategy , they maintained that it helps learners get more engaged in argumentation ,gain more confidence, form a stance and find eloquent proofs which are more thoughtful, logical and persuasive to participants.

Whether debates take place in-class or online, they must comprise viewpoints and arguments given by students through rich discussion of a particular issue. Learners endowed 
with strong critical thinking tend to think judgmentally and provide cogent ideas (Kennedy, 2007). Debate benefits students by assisting them in improving their writing skills and activating their critical thinking in conversation. According to Roy and Macchiette (2005, p. 265), "debate means not only deciding what to say but also how to say it". Finally, debate teaches students how to correctly obtain information, as well as how to interpret subject content in a cooperative manner. It also helps them to assess the information they receive and improves the writing skills of students.

In order to facilitate critical thinking, online debating takes advantage of the benefits and, of course, drawbacks of face-to-face debate. According to a study conducted by Kennedy (2007), debate encourages active participation and higher-order thinking. It encourages students to define the problem, evaluate the credibility of sources, identify and challenge the point at issue, identify inconsistencies, and prioritize the relevant claim. According to a study by Scott (2008), debate helps students to improve critical thinking skills by examining claims, studying topics, undertake research, collecting data, performing analysis, and evaluating arguments by formulating rebuttals to the opposition, challenging assumptions, and demonstrating interpersonal skills. Students must collect relevant proof of support when thinking objectively in order to provide a persuasive argument while planning for rebuttals (Tu, 2004; Bates \& Watson, 2008; Dykman \& Davis, 2009; and Saks, 2009; and Zare \& Othman, 2015).

Swain's Output Hypothesis (1993) and Long's Interaction Hypothesis (1996) support the concept that debating can be a useful pedagogical framework for the creation of FL writing. Performance, they believe, encourages learners to process language more profoundly and efficiently than reading and/or listening alone. According to Stewart (2003), debates lead to producing a lot of content because debaters have different points of view and must sell their positions. According to research, these production processes are primarily responsible for foreign language development (Manchn \& Williams, 2016). Writing, by its very nature, necessitates and focusses on form than speaking; the slower speed of writing provides learners with more flexibility and room to objectively reflect on both content and form (Manchn \& Williams, 2016).

Furthermore, debate helps learners to participate in bidirectional output exchange, allowing them to compare their output with one another, identify gaps in their FL, and address and fix problematic areas in their interlanguage (Swain, 1993). The Interaction Hypothesis is a second theoretical viewpoint that supports the notion that arguing can be a useful method for language learning (Long, 1996). Student interaction, according to Pica, Kang, and Sauro (2006), stimulates attentional processes and promotes attention to form, purpose, and context. The authors also proposed that FL learners become aware of the flaws in their input through attentional processes, allowing them to change their output.

The debate atmosphere encourages a seamless and recursive transition between the two abilities, encouraging gains to be transferred from one mode to the other. According to previous studies, learners' spoken experiences provide scaffolding for their writing progress 
(e.g., Wade, 1998; Yang, 2008; and Cho, 2017). We may expect the two modes to "mutually scaffold the transformation of intricate, multidimensional thoughts into lines of spoken and written words" in such a setting (Belcher \& Hirvela, 2008, p. 4).

According to Chen, Hand, et al. (2016) and Chen, Park, et al. (2016), the audience motivates students to create rich and persuasive reasoning. They went on to say that the audience is a crucial factor in motivating students to create more nuanced and convincing arguments, as well as connecting oral and written arguments. In a similar vein, Turgut (2009) discovered that the participation of a live audience aided the development of writing skills among FL students, who focused more on aspects of language use such as word usage.

Another aspect that can encourage students to take the learning process more seriously during debates is their positive attitude toward debate as a teaching tool (e.g., Lustigova, 2011; and el Majidi, de Graaff, \& Janssen, 2015, 2018). Lustigova (2011), for example, found that $75 \%$ of students who took a debate course in the first semester proceeded into the second semester, engaging in debate sessions for the whole academic year. In addition, there is a strong correlation between attitude towards the task being learned and its achievement, according to recent empirical studies (Dewaele et al., 2018).

In this age, students' capability to argue convincingly is sorely needed as it involves idea formulation and judging competence. Nonetheless, studies (e.g. Aclan, \& Aziz, 2015; and el Majidi, de Graaff, \& Janssen, 2015, 2018) addressing training learners on written argumentation are scarce. Being fundamental in online debate strategy, the present study advocates the use of discussion and argumentation to enhance EFL majors' argumentative writing and reduce writing apprehension.

\section{Statement of the problem}

English majors in the Faculty of Languages and Translation, Misr University for Science and Technology have difficulty producing argumentative writing and often avoid delivering the assignment for fear of negative evaluation. Thus, the study sought to investigate the effectiveness of online debating in enhancing EFL majors' argumentative writing and reducing their writing apprehension.

\section{Questions}

The following questions are raised:

1- What is the effect of online debating on developing argumentative writing performance of English majors?

2- What is the effect of online debating on reducing writing apprehension of English majors?

\section{Purpose}

The purpose of the present study is two-fold: 
1- Identifying the effect of online debating in developing argumentative writing among English majors in the Faculty of Languages and Translation.

2- Exploring the effect of online debating in reducing writing apprehension among English majors in the Faculty of Languages and Translation.

\section{Hypotheses}

The present study hypothesized the following:

1- There is a statistically significant difference between the mean scores of the experimental group and those of the control group on the post-test of argumentative writing in favor of the experimental group.

2- There is a statistically significant difference between the mean scores of the experimental group on the pre and posttest of argumentative writing in favor of the post-test.

3- There is a statistically significant difference between the mean scores of the experimental group and those of the control group on the post-test of writing apprehension in favor of the experimental group.

4- There is a statistically significant difference between the mean scores of the experimental group on the pre and posttest of writing apprehension in favor of the post-test.

\section{Significance}

The significance of the study might lie in the following points:

1- This study highlighted the importance of online debating in improving EFL majors' argumentative writing as well as reducing writing apprehension.

2- It could be useful for EFL majors to overcome the difficulties they face while writing.

3- - It could furnish language teachers and curriculum designers with online debate activities to help boost EFL majors' written argumentation skills and reduce writing apprehension.

4- The instruments constructed and employed in this study could be useful to other researchers working in the field of teaching English as a foreign language (TEFL).

5- The results of this study could be beneficial for both EFL lecturers and students in their classroom debate practice.

\section{Delimitations}

1. The treatment would be confined to the fourth year EFL majors at the Faculty of Foreign Languages and Translation, Misr University for Science and Technology.

2. Online debating, in the present research, was presented in Microsoft teams synchronously. 


\section{Definition of Terms}

\section{- Debate}

Debate was defined by Garett and Hood as an instructional method that promotes empirical reasoning and thinking skills and the increasing awareness of "attitudes," "values" and beliefs" (as cited in Ramlan, Kassim, Pakirisamy \& Selvakumar, 2016, p.196). Debate is also perceived as a type of play that gives a chance for students to share their ideas and opinions. It is a game that is based on evidence whereby students provide arguments and defend their claims to establish a better perception to the world and develop their ideas (Lee \& Nair, 2016, p.125). Debate is operationally defined as a tool which can be structured to promote a variety of critical thinking skills and motivation to develop argumentative writing and reduce writing apprehension of fourth year EFL majors at the Faculty of Foreign Languages and Translation, Misr University for Science and Technology.

\section{- Argumentative writing}

Connor (1987) gave a broad definition of argumentative writing: "written persuasive discourse integrates the rational and affective appeals" (p.185). Crowhurst (1990, p. 349) defines argumentative writing as the kind of "writing that the writers take a point of view and support it with either emotional appeals or logical appeals". Boykin (2015, p. 12-13) defined argumentative writing as "a type of writing that requires the student to investigate a topic, collect, generate, and evaluate evidence, and establish a position on the topic". Argumentative writing is operationally defined as a written discourse addressing a controversial issue, in which a position is taken, reasons and supporting ideas are presented, potential counterarguments are offered, and could be assessed via writing tests (with a scoring rubric developed in the light of Toulmin model).

\section{- Writing apprehension}

Writing apprehension is a term originally coined by Daly and Miller to describe "the fear or anxiety an individual may feel about the act of composing written materials" (Daly, 1991, p. 3). Writing apprehension is operationally defined as the degree of anxiety pertaining to argumentative writing activity that fourth year EFL majors demonstrate/indicate as manifested by their scores on the writing apprehension test.

\section{Method}

The study adopts a quasi-experimental design, comparing the performance of the experimental group to the control group to probe the effectiveness of online debating in developing EFL majors' argumentative writing and reducing writing apprehension.

\section{Design and Participants}

The current research participants were 50 fourth year EFL majors at the Faculty of Foreign Languages and Translation, Misr University for Science and Technology. During the academic year (2020/2021), they were randomly selected and assigned into an experimental 
group (25) and a control one (25). For the purposes of this study, the experimental group students participated in a debate training (once a week, totaling 11 weeks), while the control group students received the regular training of argumentative essay writing. The regular writing course is reduced to assigning topics and correcting errors of grammar with little care, if any, to technicalities of writing.

\section{Instruments}

To fulfill the purpose of the present study, data collection instruments were developed to measure the participants' responses on the study variables. Two main instruments were required for the present study:

\section{The Argumentative Writing Test}

An argumentative writing test with a scoring rubric for assessing the participants' argumentative writing skills was developed. The layout of the test comprised the stages of the writing process: planning (develop your ideas about the topic), text production (writing the first draft), revising and finally writing the final copy of the topic. Students were asked to write at least 250 words about the assigned topic. The total score of the test was 30 marks. A 5-point scoring rubric with 6 dimensions for rating students' writing was used.

\section{The Writing Apprehension test}

Daly and Miller -Writing Apprehension test (DM-WAT) consisted of 26 items in the format of Likert-type scale, each with 5 possible responses ranging from "strongly agree" to "strongly disagree".

\section{Treatment}

\section{The online debating program}

- Based on discussion and argumentation, debating program included activities of recognizing students' views on various topics in which they were required to take a pro or con stance on each issue. Exercising argumentation and counter-argumentation of online debatable topics, could help EFL majors improve their argumentative writing and reduce their writing apprehension.

- The different activities of debate were exercised using Microsoft teams.

- There were three phases to each debate: persuasive voice, rebuttal, and clash (see, e.g., Snider \& Schnurer, 2006). There were three stages of each debate: pre-debate, debate, and post-debate (detailed description of the steps of the program are presented in the procedures below).

\section{Procedures of the Study}

The participants were pretested on argumentative writing and DM- writing apprehension before the treatment. Students of the experimental group were exposed to the 
sessions of online debating program via Microsoft Teams during the first term of the 20202021 academic year. The treatment lasted 11 weeks including the pre-and posttest sessions. The duration of each training session was approximately 3 hours. The activities of the program included recognition of students' opinions towards different controversial topics of each debate (e.g. Drug addicts: Do they need help or punishment? Should children use smartphones without parental supervision?). The students had to adopt a point of view of being for or against each topic of discussion. In the pre-debate stage, students were required to read and summarize two papers, one of which was selected by the instructor, and the students were required to find the second. During debate stage, students were asked to take notes of the opponents to rebut them in the rebuttal and clash stages. Finally, in the postdebate stage, the feedback provided by the instructor on written argumentative essays was processed. Opposing views were often raised but as logic was adopted as a frame of reference, gaps were narrowed. After finishing the treatment sessions, the argumentative writing and DM- writing apprehension posttests were administered to the participants of the study. Writing answers and writing apprehension responses were evaluated and calculated for each student using the scoring rubric described earlier. The data were calculated using SPSS to determine any differences between pre and posttests scores among the research sample.

\section{Results and Discussion}

\section{The first hypothesis}

To verify the first hypothesis signifying that "there is a statistically significant difference between the mean scores of the experimental group and those of the control group on the post-test of argumentative writing in favor of the experimental group", taking into account the nature of the hypothesis proposed, one sample t-test was utilized. Precisely, a comparison between the post-test mean scores of the experimental group and the control one was held to figure out the differences in the argumentative writing before and after the treatment. The following table (1) displays the results of the statistical analysis.

\section{Table (1)}

The " $t$ " Value of the Experimental Group and the Control Group on the Post Administration of the Argumentative Writing Test

\begin{tabular}{lcccccc}
\hline Group & $\mathbf{N}$ & Mean & $\begin{array}{c}\text { Std. } \\
\text { Deviation }\end{array}$ & df & t & $\begin{array}{c}\text { Sig. (2 } \\
\text { tailed) }\end{array}$ \\
\hline EX & 25 & 8.97 & 1.55 & 48 & 4.6 & 0.000 \\
Con & 25 & 7.32 & 1.32 & & & \\
\hline
\end{tabular}

Table (1) above shows that the number of the study participants in the experimental group was 25 and that of the control was 25 EFL majors in the Faculty of Languages and Translation, Misr University for Science and Technology. It also demonstrates that the mean 
scores of the experimental group was 8.97 and that of the control group was 7.32 with a standard deviation of $1.55 \& 1.32$ respectively and a freedom degree of (48). The last cell of the table disclosed the value of the $t$ (4.6). These results indicate that the higher mean is in favor of the experimental group. So, the first hypothesis is accepted.

\section{The second hypothesis}

To verify the second hypothesis uttering "there is a statistically significant difference between the mean scores of the experimental group on the pre and posttest of argumentative writing in favor of the post-test", a paired sample t-test was employed because of the nature of the hypothesis. Precisely, a comparison was held between the pre and posttests mean scores of the experimental group to statistically discover the difference in their argumentative writing before and after the treatment. The subsequent table (2) outlines the results of the statistical analysis obtained:

\section{Table (2)}

Results of Paired Samples t-test Comparing the Mean Scores of the Experimental Group on the Pre and Posttest of Argumentative Writing

\begin{tabular}{ccccccc}
\hline Test & N & Mean & $\begin{array}{c}\text { Std. } \\
\text { Deviation }\end{array}$ & df & t & $\begin{array}{c}\text { Sig. (2 } \\
\text { tailed) }\end{array}$ \\
\hline Pretest & 25 & 6.83 & 1.43 & 24 & 5.80 & 0.000 \\
Posttest & & 8.97 & 1.55 & & & \\
\hline
\end{tabular}

The data exposed in table (2) above outlines the number of study participants (25) followed by the method of treatment (pre-post). It also illustrates the calculated means of the students' responses which are $(6.83 \& 8.97)$ in the pre-posttest respectively. The table also demonstrates the value of the standard deviation in the pre posttests which was respectively $(1.43 \& 1.55)$. The penultimate cell degree is the freedom degree (24) followed by the calculated results of the $t$ value (5.80). These results indicate that the higher mean is in favor of the post-test. So, the second hypothesis is accepted.

\section{The third hypothesis}

To verify the third hypothesis stating that "there is a statistically significant difference between the mean scores of the experimental group and those of the control group on the post-test of writing apprehension in favor of the experimental group", taking into account the nature of the hypothesis proposed, one sample t-test was utilized. Precisely, a comparison was drawn between the post-test mean scores of the experimental group and that of the control group to figure out the changes in the writing apprehension before and after the treatment. The following table (3) displays the results of the statistical analysis. 


\section{Table (3)}

The " $t$ " Value of the Experimental Group and the Control Group on the Post Administration of the Writing Apprehension Test

\begin{tabular}{lcccccc}
\hline Group & $\mathbf{N}$ & Mean & $\begin{array}{c}\text { Std. } \\
\text { Deviation }\end{array}$ & df & t & $\begin{array}{c}\text { Sig. (2 } \\
\text { tailed) }\end{array}$ \\
\hline EX & 25 & 8.47 & 1.84 & 48 & 3.94 & 0.000 \\
Con & 25 & 6.81 & 1.41 & & & \\
\hline
\end{tabular}

The data provided in table (3) above depicts the number of the study participants in the experimental group which was 25 and that of the control group which was 25 . In addition, the mean scores of the experimental group was 8.47 and that of the control group was 6.81 with a standard deviation of $1.84 \& 1.41$ respectively and a freedom degree of (48). The last cell of the table reveals the value of the $t$ (3.94). These results indicate that the higher mean is in favor of the experimental group. So, the third hypothesis is accepted.

\section{The fourth hypothesis}

To verify the fourth hypothesis stating "there is a statistically significant difference between the mean scores of the experimental group on the pre and posttest of writing apprehension in favor of the post-test", a paired sample t-test was employed due to the nature of the hypothesis stated. Specifically, a comparison was drawn between the pre and posttests mean scores of the experimental group to statistically discover the difference in their writing apprehension before and after the treatment. The following table (4) presents the results of the statistical analysis obtained:

\section{Table (4)}

Results of Paired Samples t-test Comparing the Mean Scores of the Experimental Group on the Pre and Posttest of Writing Apprehension

\begin{tabular}{ccccccc}
\hline Test & $\mathbf{N}$ & Mean & $\begin{array}{c}\text { Std. } \\
\text { Deviation }\end{array}$ & df & t & $\begin{array}{c}\text { Sig. (2 } \\
\text { tailed) }\end{array}$ \\
\hline Pretest & 25 & 6.71 & 1.35 & 24 & 4.76 & 0.000 \\
Posttest & & 8.47 & 1.84 & & & \\
\hline
\end{tabular}

The data shown in table (4) above delineates the number of study participants (25) followed by the type of treatment (pre-post). Besides, the table shows the calculated means of the students' responses which was $(6.71 \& 8.47)$ in the pre-posttest respectively. The table, furthermore, illustrates the value of the standard deviation in the pre posttests respectively 
(1.35 \& 1.84). The penultimate cell degree overviews the freedom degree (24) followed by the calculated results of the $t$ value (4.76). These results indicate that the higher mean is in favor of the post-test. So, the fourth hypothesis is accepted.

It seems reasonable to conclude that using online debating to improve EFL majors' argumentative writing and reduce writing apprehension is successful, based on the findings. Armed with training on the structural features of online debating strategy characterized by formality, complexity, knowledgeability and logicality, the experimental group students were able to gather evidence-based data that support their standpoints and consequently refute the opponents' arguments, resulting in significant differences in their favor.

These findings suggest that using debate strategy is instrumental in developing critical thinking and interactive argumentation, both of which are crucial in argumentation. The results of the study are consistent with the studies of Park, Kier \& Jugdev (2011); Peace (2011); Tollison \& Xie (2012); Yang \& Rusli (2012); Sziarto et al (2014); Aclan (2015); Tous et al (2015); Lopez et al (2016); Jeong \& Liu (2017); and Mumtaz (2017).

A second interpretation for the improvement attained in favor of the experimental group is the novelty of the pedagogy adopted (online debating) which helped them plan writing, put words together in a meaningful way and revise their written products, processes they had never been exposed or paid attention to in a conventional writing classroom. In addition, the fact that the experimental group students received training on articulating and defending their stances, practicing gap detection in each other's arguments and assessing the validity of one's own ideas in comparison with others, all operating together or some of them could have contributed to higher performance in their favor.

A third explanation in support of the results reached is the feature of flexibility characterizing online debating. The instructors benefit from online debate in tracking the students' participation with colleagues because of the flexibility of time. The adaptability of online debate encourages students to explore varied sources, including both paper-based and digital content. According to recent research, online learning environments enable students and instructors to control their own time doing tasks without having to meet face-to-face (Jeffrey, et al., 2014; Petrides, 2002; and Yang, \& Cornelius, 2004), as well as pace of learning (Liang \& Chen, 2012). Owing to the extra time to process the materials before reacting to other claims, the students become highly autonomous in learning, including the ability to discover more sources. However, the role assumed by the instructor is crucial in online learning because her/his absence in online discussions can cause anxiety for students, particularly in problem-solving sessions (Arend, 2009), and cause students to jump from claim to solution without proper review (Garcia et, al, 2008).

The results reached highlight the contribution of online debate in critical thinking among students. According to the results of the test, the students showed higher order thinking skills that demonstrated their critical thinking abilities expressed in the cogency and persuasiveness of their evidence-based arguments. These results support those reached by other studies who examined analytical thinking in online debate to help students in providing 
logical evidence to support their claims (Tu, 2004), thinking more profoundly in writing than verbal answers, conducting analysis in rebutting argument (Scott, 2008), and improving ability to take a stand on the debate (Khalsi, 2013; and Park, Kier, \& Jugdev, 2011). These studies are in line with the results of the present study that online interaction and debate can help students develop critical thinking skills.

In the previous studies reported, online debate has proven to be a powerful tool for fostering critical thinking among students. The adequate format of online debate assigns specific roles and procedures to students to ensure that they are learning meaningfully. The students were guided to apply their best thinking and produce reflective and considered responses to defend their claims (Krathwohl, 2002). The results of the present study gave prominence to the fact that online debate pedagogy stimulated students positive response to write and exercise higher order reasoning skills while writing an argumentative essay, making the best use of the technique of data gathering and the logical proofs submitted to refute the opposing teams claims.

The results obtained in the present study revealed that the experimental group students had not only more depth of thought but gave more details in their attempt to persuade both the instructor and the opposing team than debates held in typical classroom. This explanation is confirmed by Ko and Rossen (2008), who argue that online discussions often generate dialogue that is both more thoughtful and reasoned than dialogue generated in traditional classrooms. Furthermore, the online classroom "provides a secure space for students who are more anxious, ordinarily may not join, too timid to participate in discussions with others who are louder or domineering (Ko and Rossen, 2008, p. 14)".

Being the gate to academic achievement and crucial for career success, performing writing creates anxiety and often puts students under pressure the moment they are required to do the demanding and challenging task of writing assignments. This is confirmed by recent literature maintaining the stress students would experience if they were asked to produce a written product (Daud et al., 2005). As regards results indicating the improvement attained in favor of the experimental group students in writing apprehension, it could be attributed to the advantage of planning characterizing the new pedagogy. The apprehension experienced by the control group, it could be argued, may be attributed to lack of planning on the part of the students, a tool needed to cope with situation-specific anxiety.

Finally, there is evidence that students' output improved both on the cognitive and affective spheres. Cognitively, performance improved following exposure to online debating activities which could be attributed to the exercise on argumentation and counterargumentation where debaters have to take a position for or against based on available facts and reasoning. Affectively, apprehension has been reduced as a result of the secure embarrassment-free atmosphere made available through online debating pedagogy. 


\section{Summary and Conclusion}

In the present study, the attempt was made to investigate the effects of training on online debate to enhance argumentative writing and reduce writing apprehension. Results strongly advocated the value of online debate as a pedagogy that provide time flexibility and secure environment. Audience availability has also raised motivation due to gaining higher self-image in the eyes of classroom counterparts, resulting in better performance and producing substantially longer texts in favor of the experimental group students.

Students' argumentative writing performance remarkably develops as they use online debate. Students improve their ability to perform and defend ideas during the debate activity. Debate challenges students to defend their arguments in the best possible way in order to win the debate. This encourages students to think more quickly and correctly produce relevant opinions or ideas in a short period of time. As a result, the student must have a thorough understanding of the subject.

In this activity, students work cooperatively to find the best argument to refute the one submitted by their opponent, whether it is a personal debate activity (one-on-one) or a group debate activity (working together with a partner). This exercise encourages students to defend their point of view on the problem and demonstrate their understanding of the issue. Furthermore, the debate atmosphere appears to promote the growth of students' metacognitive understanding of the processes that contribute to the creation of writing. This setting, for example, seems to inculcate in students the understanding that using sophisticated, coherent, and precise language improves the persuasiveness of their arguments. Ultimately, learners' satisfaction with debating, its competitive nature and the involvement of a live audience (i.e., the instructor and colleagues) seem to provide additional incentives for learners to give importance to various aspects of language use and argumentative content.

Since English writing ability is critical to university students' academic and professional success, it is crucial to assist them in improving their writing performance and consolidate their weaknesses. This research intended to investigate the effect of using online debate in improving EFL majors' argumentative writing skills and reducing their writing apprehension. Participants demonstrated that writing apprehension had a negative effect on their writing output and consequently they avoided writing, feeling reluctant to begin, were dissatisfied with their writing ability and were unable to take part with colleagues during class time.

Teachers of English at the university level must be aware of their students' attitude towards writing, use online debate to teach writing, and encourage their students to practice writing by introducing more learner-centered activities and giving students more autonomy in classroom activities. When students have more control of how they learn and do things, they gain confidence and develop a positive attitude toward the written word. When such a condition is facilitated, it will almost certainly result in improved argumentative writing and reduce apprehension. These findings are consistent with previous research, such as (Daud et al., 2005; Khan, 2011; and Mo, 2012). Although research is growing in this area, more studies 
in diversified contexts are sorely needed to get a more comprehensive picture about this demanding issue.

\section{Recommendations}

Based on the results attained, the recommendations below seem pertinent:

1- As online debating proved effective in enhancing EFL writing, teaching structural features of debating should be given prominence in language pedagogy curriculum.

2- When developing training programmes for enhancing writing performance and reducing writing apprehension for EFL learners, the affective variables related to the writing process should be accorded adequate attention.

3- In teaching writing, EFL teachers should abandon the product-centered approach, in which they solely concentrate on the finished product, in favour of the processcentered approach, in which the focus is primarily on the writing process itself.

4- As language skills are integrative and making use of current research on writing to read, the writing processes experienced through debating should be made use of as a scaffolding to develop critical reading among EFL majors.

5- In the present study, the attempt was made to examine the effect of online debating on enhancing argumentative writing and reducing apprehension. Future investigators might wish to explore using multimedia -based training curriculum for improving writing performance and developing better attitude towards writing.

6- Owing to the crucial importance of using prior knowledge in developing writing, a writing training program based on constructivism theory could be effective in enhancing writing performance.

\section{References}

Aclan, E. et al. (2015). Why and how EFL students learn vocabulary in parliamentary debate class. Advances in Language and Literary Studies, 6(1) 102-113.

Al-Shboul, Y., \& Huwari, I. F. (2015). The causes of writing apprehension through students' perspective. Journal of Language Teaching and Research, 6(3), 535-544.

Arend, B. (2009). Encouraging critical thinking in online threaded discussions. Journal of Educators Online, 6(1), 1-23.

Atay, D., \& Kurt, G. (2006). Prospective teachers and L2 writing anxiety. Asian EFL Journal, $8(4)$.

Autman, H., \& Kelly, S. (2017). Reexamining the writing apprehension measure. Business and Professional Communication Quarterly, 80(4), 516-529.

Badger, R., \& White, G. (2000). A process genre approach to teaching writing. ELT Journal, $54,153-160$. 
Bailey, S. (2003). Academic writing: A practical guide for student. New York: Nelson Thornes Ltd.

Bates, C. \& Watson, M. (2008) Re-learning teaching techniques to be effective in hybrid and online courses. Journal of American Academy of Business 13(1), 38-44.

Belcher, D., \& Hirvela, A. (Eds.). (2008). The oral-literate connection: Perspectives on L2 speaking, writing, and other media interactions. Ann Arbor, MI: The University of Michigan Press.

Bellon, J., (2000). A research-based justification for debate across the curriculum. Argumentation and Advocacy, 36(3), 161-173.

Boykin, A. (2015). The impact of computer-based graphic organizers with embedded selfregulated learning strategies on the content area argumentative writing of typical and struggling Writers. (Doctoral Dissertation, George Mason University).

Chen, Y., Hand, B., \& Park, S. (2016). Examining elementary students' development of oral and written argumentation practices through argument-based inquiry. Science \& Education, 25, 277-320.

Chen, Y., Park, S., \& Hand, B. (2016). Examining the use of talk and writing for students' development of scientific conceptual knowledge through constructing and critiquing arguments. Cognition and Instruction, 34, 100-147.

Cheng, Y. (2002). Factors associated with foreign language writing anxiety. Foreign Language Annals, 35(5), 647-656.

Cho, H. (2017). Synchronous web-based collaborative writing: Factors mediating interaction among second-language writers. Journal of Second Language Writing, 36, 37-51.

Clark, D. (2005). Explorations into writing anxiety: Helping students overcome their fears and focus on learning. ISSOTL Conference.

Connor, U. (1990). Linguistics/Rhetorical measures for international persuasive student writing. Research in the Teaching of English. 24 (1), 67-87.

Conrad, R., \& Donaldson, A. (2004). Engaging the online learner: Activities and resources for creative instruction. San Fansisco: Jossey-Bass.

Crowhurst, M. (1990). Teaching and learning the writing of persuasive/argumentative Discourse. Canadian Journal of Education. 15 (4), 348-359.

Daly, J. (1991). Understanding communication apprehension: An introduction for language educators. In E. Horwitz \& D. Young (Eds.), Language anxiety: From theory and research to classroom implications (pp. 3-13). New Jersey: Prentice Hall. 
Daly, J., \& Miller, M. (1975). Apprehension of writing as a predictor of message intensity. The Journal of Psychology, 89(2), 175-177.

Daud, N. S., Daud, N. M., \& Kassim, N. L. (2005). Second language writing anxiety: Cause or effect. Malaysian Journal of ELT, 1(1), 1-19.

Dewaele, J., Witney, J., Saito, K., \& Dewaele, L. (2018). Foreign language enjoyment and anxiety: The effect of teacher and learner variables. Language Teaching Research, 22, 679-697.

Dykman, C. \& Davis, C. (2009). Online education forum: Part two - teaching online versus teaching conventionally. Journal of Information Systems Education 19(2), 157-164.

el Majidi, A., de Graaff, R., \& Janssen, D. (2015). Invest in what energizes students to learn: Investigating students' attitude towards debate in the foreign language classroom. Journal of Language Teaching and Research, 6, 924-932.

el Majidi, A., de Graaff, R., \& Janssen, D. (2018). Students' perceived effect of in-class debates in second language learning. The European Journal of Applied Linguistics and TEFL, 7, 35-57.

Erkan, D., \& Saban, A. (2011). Writing performance relative to writing apprehension, selfefficacy in writing, and attitudes towards writing: A correlational study in Turkish tertiary-level EFL. The Asian EFL Journal Quarterly, 13(1), 164-192.

Ferretti, R., Andrews-Weckerly, S., \& Lewis, W. (2007). Improving the argumentative writing of students with learning disabilities: Descriptive and normative considerations. Reading \& Writing Quarterly, 23(3), 267-285.

Flores, R. (2006) Thinking skills reflected in the argumentative essays of freshman college students: A descriptive analysis. The Asia Pacific-Education Researcher, 16(1), 33-44.

García, B., Márquez, L., Bustos, A., Miranda, G., \& Espíndola S. (2008). Analysis of patterns of interaction and knowledge construction in online learning environments: A methodological strategy. Revista Electrónica de Investigación Educativa, 10 (1), 1-18.

Golpour. F. (2014). Critical thinking and EFL learners' performance on different writing modes. Pan-Pacific Association of Applied Linguistics, 18(1), 103-119.

Hammann, L. (2005). Self-regulation in academic writing tasks. International journal of teaching and learning in higher education, 17(1), 15-26.

Hashemi M., Behrooznia, S., \& Mahjoobi F. (2014). A critical look into Iranian EFL university students' critical thinking and argumentative writing. Iranian Journal of Applied Linguistics (IJAL), 17(1), 71-92. 
Hasibuan, A., \& Batubara, I. (2012). Implementing problem-based learning in digitalization era through debating practice. Proceedings of the 59th TEFLIN International Conference (pp. 13-30). Surabaya: Widya Mandala Catholic University.

Hirvela, A. (2017). Argumentation \& second language writing: Are we missing the boat? Journal of Second Language Writing, 36, 69-74.

Jeffrey, L. M., Milne, J., Suddaby. G., \& Higgins, A. (2014). Blended learning: How teachers balance the blend of online and classroom components. Journal of Information Technology Education Research, 13, 121-140.

Jeong, A. \& Liu, Z. (2017). The effects of prior beliefs on student interactions in online debates. TechTrends: Linking Research and Practice to Improve Learning, 61(2), 115120.

Ka-kan-dee M. \& Kaur S (2015). Teaching Strategies Used by Thai EFL Lecturers to Teach Argumentative Writing. Procedia - Social and Behavioral Sciences, 208.

Kara, S. (2013). Writing Anxiety: A Case study on students' reasons for anxiety in writing. Anadolu Journal of Educational Sciences International, 3(1).

Kennedy, R. (2007). In-class debates: Fertile ground for active learning and the cultivation of critical thinking and oral communication skills. International Journal of Teaching and Learning in Higher Education, 19(2), 183-190.

Khalsi, I. (2013). Knowledge construction and gender in online debates. AWEJ, 4(2), 310326.

Khan, A., (2011). Role of applied linguistics in the teaching of English in Saudi Arabia. International Journal of English Linguistics, 1(1), 105-114.

Ko, S., \& Rossen, S. (2008). Teaching online: A practical guide, 2nd edition. New York, New York.

Krathwohl, D. (2002). A revision of Bloom's taxonomy. Theory into Practice, 41(4), 212 218.

Lee, E., \& Nair, A. (2016). A culture of humility and debate. In K.A. Davis, M.L.W. Zorwick, J. Roland, \& M.M. Wade (Eds.), Using debate in the classroom: Encouraging critical thinking, communication (pp.117-129). New York: Routledge.

Liang, R., \& Chen, D. (2012). Online learning: Trends, potential and challenges. Scientific Research, 3(8), 1332-1335.

Long, M. (1996). The role of the linguistic environment in second language acquisition. In W. Ritchie \& T. Bhatia (Eds.), Handbook of second language acquisition (pp. 413-468). New York: Academic Press. 
López, G. et al. (2016). A debate and decision-making tool for enhanced learning. IEEE Transactions on Learning Technologies, 9(3), 205-216.

Lustigova, L. (2011). Speak your mind: Simplified debates as a learning tool at the university level. Journal of Efficiency and Responsibility in Education and Science, 4, 18-30.

MacKnight, C. (2000). Teaching critical thinking through online discussions. Educause Quarterly, 4, 38-41.

Manchn, R., \& Williams, J. (2016). L2 writing and SLA studies. In R. Manchon \& P. K. Matsuda (Eds.), The handbook of second and foreign language writing (pp. 567-586). Boston: de Gruyter.

Mo, H. (2012). A study of the teaching of ESL writing in colleges in China. International Journal of English Linguistics, 2(1), 118-127.

Mont, M. (2014). The use of debates in higher education classrooms. Proceedings for the 2014 Adult Education Research Conference. Retrieved from: http://www.adulterc.org/Proceedings/2014/roundtables/Mont.pdf.

Mumtaz, L. (2017). Learning through debate during problem-based learning: An active learning strategy. Advances in Physiology Education, 31 ,3 390-394.

Neff-van Aertselaer, J., \& Dafouz-Milne, E. (2008). Argumentation patterns in different languages: An analysis of metadiscourse markers in English and Spanish texts. Developing contrastive pragmatics: Interlanguage and cross-cultural perspectives, 87102.

Nikou, F., Bonyadi, A., \& Amirikar, N. (2015). Investigating the relationship between critical thinking skills and the quality of Iranian intermediate TEFL students' writing. Advances in Language and Literary Studies, 6(2), 57-64.

Nippold, M., \& Ward-Lonergan, J. (2010). Argumentative writing in pre-adolescents: The role of verbal reasoning. Child Language Teaching and Therapy, 26(3), 238-248.

Onwuegbuzie, A. (1997). Writing a research proposal: The role of library anxiety, statistics anxiety, and composition anxiety. Library \& Information Science Research, 19(1), 533.

Oshima, A., \& Hoggue, A. (2005). Writing academy English (4th ed.). New York: Longman Ltd.

Öztürk, H., \& Çeçen, S. (2007). The effects of portfolio keeping on writing anxiety of EFL students. Journal of Language and Linguistic Studies, 3(2), 219-236.

Park, C. Kier, C. \& Jugdev, K. (2011). Debate as a teaching strategy in online education: A case study. Canadian Journal of Learning and Technology, 37(3), 1-17. 
Peace, A. (2011). Using debates to teach information ethics. Journal of Information Systems Education, 22 ,3 233-237.

Petrides, L. A. (2002). Web-based technologies for distributed (or distance) learning: Creating learning-centered educational experiences in the higher education classroom. International Journal of Instructional Media, 29(1), 69-77.

Pica, T., Kang, H., \& Sauro, S. (2006). Information gap tasks: Their multiple roles and contributions to interaction research methodology. Studies in Second Language Acquisition, 28, 301-338.

Pradana,S. (2017). Using Debate to Enhance Students' Speaking Ability as Their Character Building. English Education: Jurnal Tadris Bahasa Inggris, 10(1), 149-163.

Qin, J., \& Karabacak, E. (2010). The analysis of Toulmin elements in Chinese EFL university argumentative writing. System, 38, 444-456.

Ramlan, F., Kassim, N., Pakirisamy, S., \& Selvakumar, V. (2016). The impact of debates as a teaching strategy in the classroom to medical students. e-Academia Journal. 5(2). 194203.

Rankin-Brown, M. (2006). Addressing writing apprehension in adult English language learners. Paper presented at the Proceedings of the CATESOL state conference.

Richards, J., \& Schmidt, R. (2010). Longman dictionary of language teaching and applied linguistics ( $4^{\text {th }}$ ed.). London: Longman (Pearson Education).

Roy, A., \& Macchiette, B. (2005). Debating the issues: A tool for augmenting critical thinking skills of marketing students. Journal of Marketing Education, 27(3), 264-276.

Saks, D. (2009). Education at a distance: Best practices and considerations for leadership educators. Journal of Leadership Education 8(1), 137-147.

Samanhudi, U. (2011). Researching students' critical thinking in argumentative writing: A case study in one state University in Serang, Banten (Unpublished Thesis). Indonesia University of Education, Bandung, Indonesia.

Schwarz, B., Neuman, Y., Gil, J., \& Ilya, M. (2003). Construction of collective and individual knowledge in argumentation activity. Journal of the Learning Sciences, 12(2). 219256.

Scott, S. (2008). Perception of students' learning critical thinking through debate in technology classroom: A case study. The Journal of Technology Studies, 34(1), 39-44.

Shahsavar, Z. (2012). Developing critical thinking skills in the argumentative writing of tertiary level students a blended learning environment (Unpublished $\mathrm{PhD}$ Thesis). Universiti Putra Malaysia, Serdang, Malaysia. 
Singh, T., \& Rajalingam, S. (2012). The Relationship of Writing Apprehension Level and Self-efficacy Beliefs on Writing Proficiency Level among Pre-university Students. English Language Teaching, 5(7). 42-52.

Snider, A., \& Schnurer, M. (2006). Many sides: Debate across the curriculum. New York: International Debate Education Association.

Stewart, T. (2003). Debate for ESOL students. TESOL Journal, 12, 9-15.

Swain, M. (1993). The output hypothesis: Just speaking and writing aren't enough. The Canadian Modern Language Review, 50, 158-164.

Sziarto, K. et al. (2014). Teaching critical thinking in world regional geography through stakeholder debate. Journal of Geography in Higher Education, 38 (4), 557-570.

Takahashi, A. (2009). Self-perception of English Ability: Is it related to proficiency and/or class performance? Niigata Studies in Foreign Languages and Cultures, 14, 39-48.

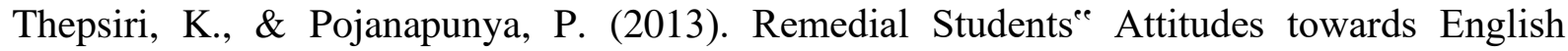
Language Learning and their Causal Attributions for Success or Failure. Humanities and Social Sciences, 29(1), 25-50.

Tollison, S \& Xie, K. (2012). Preparing students in online debates with worked examples. Educational Computing Research, 47 ,2 155-174.

Tous, M. et al. (2015). The effect of instructing critical thinking through debate on male and female EFL learners' reading comprehension. Journal of the Scholarship of Teaching and Learning, 15(4), 21-40.

Tu, C-H. (2004). Online collaborative learning communities: twenty-one designs to building an online collaborative learning community. Westport, CT: Libraries Unlimited, Greenwood Publishing Group.

Turgut, Y. (2009). EFL learners' experience of online writing by PBWiki. In G. Siemens \& C. Fulford (Eds.), ED-MEDIA 2009-World conference on educational multimedia, hypermedia, \& telecommunications (pp. 3838-3847). Waynesville, NC: AACE.

Vanhille, J., Gregory, B., \& Corser, G. (2017). The effects of mood on writing apprehension, writing self-efficacy, and writing performance. PSI CHI Journal of Psychological Research, 22(3), 220-230.

Wade, M. (1998). The case for urban debate league. Contemporary Argumentation and Debate, 19, 60-65.

Watcharakaweesilp, S. (2005). The use of English S1-Test for Accessing General Language Proficiency for Non-native speakers in High School. Humanities and Social Sciences, 22(3), 1-76. 
Williams, C. \& Mostert, M. (2005). Online debating to encourage student participation in online learning environments: A qualitative case study at a South African university. International Journal of Education and Development using Information and Communication Technology (IJEDICT), 1(2), 94-104.

Wu, S. (2006). Creating a contrastive rhetorical stance: investigating the strategy of problematization in students' argumentation. RELC Journal, 37(3), 329-353.

Yang, C. \& Rusli, E. (2012). Using debate as a pedagogical tool in enhancing pre-service teachers' learning and critical thinking. Journal of International Education Research, 8 ,2,135-144.

Yang, L. (2008). From group talk to group writing. In D. Belcher \& A. Hirvela (Eds.), The oral-literate connection: Perspectives on L2 speaking, writing and other media interactions (pp. 139-167). Ann Arbor, MI: The University of Michigan Press.

Yang, Y., \& Cornelius, L. (2004). Students' perception towards the quality of online education: A qualitative approach. Association for Educational Communication and technology, 27, 861-877.

Zare P. \& Othman M. (2015). Students' perceptions toward using classroom debate to develop critical thinking and oral communication ability. Asian Social Science, 11(9), 1911-2025.

Zohar, A., \& Nemet, F. (2002). Fostering students' knowledge and argumentation skills through dilemmas in human genetics. Journal of Research in Science Teaching: The Official Journal of the National Association for Research in Science Teaching, 39(1), $35-62$.

Zumbrunn, S., Bruning, R., Dempsey, M., Kauffman, D., \& McKim, C. (2013). Examining dimensions of self-efficacy for writing. Journal of Educational Psychology, 105(1), 25-38. 


\title{
أثر استراتجية المناظرة عبر الانترنت في تنمية الكتابة الجلية و خفض الرهبة منها لاي طلاب شعبة اللغة الاتجليزية
}

\author{
د. حنان جمال محمد عبيدى \\ مدرس المناهج و طرق تدريس اللغة الانجليزية \\ جامعة مصر للعلوم و التكنولوجيا
}

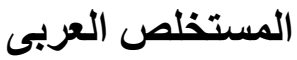

استهدفت الدر اسة الحالية بحث فاعلية المناظرة عبر الإنترنت في تتمية الكتابة الجدلية و علاقتها

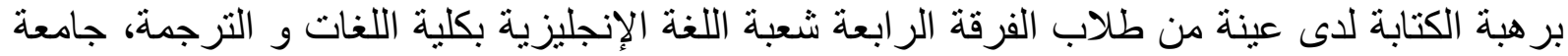

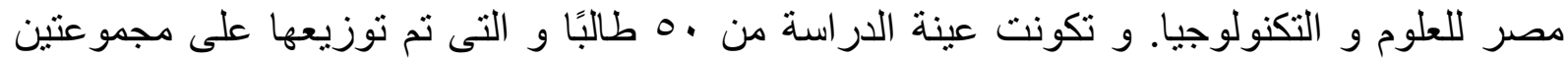

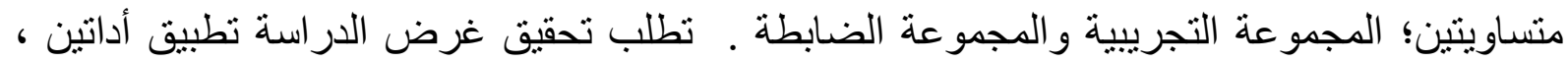
أولهما أختبار الكتابة الجدلية وثانيهما اختبار رهبة الكتابة لدالي وميلر. و قد تم تطبيق اختبار الكتابة الجدلية و اختبار رهبة الكتابة قبليا و بعديا على كل من المجموعتين الضابطة و التجريبية. تلقي طلاب التهاب

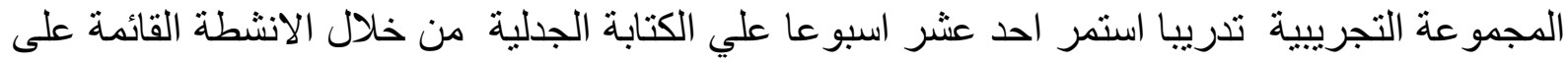
طريقة المناظرة عبر الإنترنت، بينما تلقى طلاب المجموعة الضابطة تدريبهم بالطريقة المعتادة. أشنارت

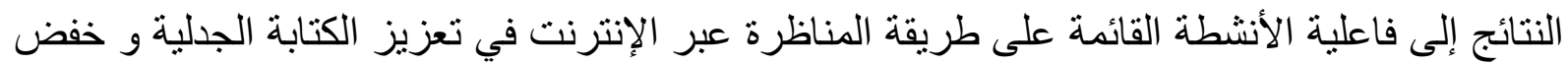

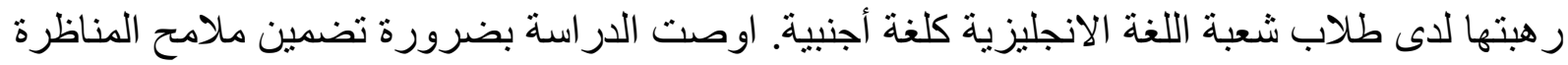
في مناهج تدريس اللغة .

الكلمات المفتاحية: المناظرة عبر الانترنت ـ الكتابة الجدلية ـ رهبة الكتابة

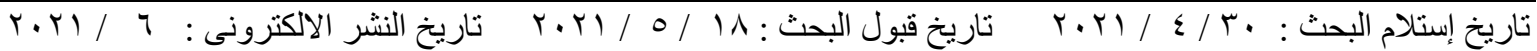

